\title{
Thermal and X-ray diffraction analysis studies during the decomposition of ammonium uranyl nitrate
}

\author{
B. H. Kim • Y. B. Lee • M. A. Prelas • \\ T. K. Ghosh
}

Received: 14 November 2011 / Published online: 3 January 2012

(C) The Author(s) 2011. This article is published with open access at Springerlink.com

\begin{abstract}
Two types of ammonium uranyl nitrate $\left(\mathrm{NH}_{4}\right)_{2} \mathrm{UO}_{2}\left(\mathrm{NO}_{3}\right)_{4} \cdot 2 \mathrm{H}_{2} \mathrm{O}$ and $\mathrm{NH}_{4} \mathrm{UO}_{2}\left(\mathrm{NO}_{3}\right)_{3}$, were thermally decomposed and reduced in a TG-DTA unit in nitrogen, air, and hydrogen atmospheres. Various intermediate phases produced by the thermal decomposition and reduction process were investigated by an $\mathrm{X}$-ray diffraction analysis and a TG/DTA analysis. Both $\left(\mathrm{NH}_{4}\right)_{2} \mathrm{UO}_{2}\left(\mathrm{NO}_{3}\right)_{4}$. $2 \mathrm{H}_{2} \mathrm{O}$ and $\mathrm{NH}_{4} \mathrm{UO}_{2}\left(\mathrm{NO}_{3}\right)_{3}$ decomposed to amorphous $\mathrm{UO}_{3}$ regardless of the atmosphere used. The amorphous $\mathrm{UO}_{3}$ from $\left(\mathrm{NH}_{4}\right)_{2} \mathrm{UO}_{2}\left(\mathrm{NO}_{3}\right)_{4} \cdot 2 \mathrm{H}_{2} \mathrm{O}$ was crystallized to $\gamma-\mathrm{UO}_{3}$ regardless of the atmosphere used without a change in weight. The amorphous $\mathrm{UO}_{3}$ obtained from decomposition of $\mathrm{NH}_{4} \mathrm{UO}_{2}$ $\left(\mathrm{NO}_{3}\right)_{3}$ was crystallized to $\alpha-\mathrm{UO}_{3}$ under a nitrogen and air atmosphere, and to $\beta-\mathrm{UO}_{3}$ under a hydrogen atmosphere without a change in weight. Under each atmosphere, the reaction paths of $\left(\mathrm{NH}_{4}\right)_{2} \mathrm{UO}_{2}\left(\mathrm{NO}_{3}\right)_{4} \cdot 2 \mathrm{H}_{2} \mathrm{O}$ and $\mathrm{NH}_{4} \mathrm{UO}_{2}$ $\left(\mathrm{NO}_{3}\right)_{3}$ were as follows: under a nitrogen atmosphere: $\left(\mathrm{NH}_{4}\right)_{2} \mathrm{UO}_{2}\left(\mathrm{NO}_{3}\right)_{4} \cdot 2 \mathrm{H}_{2} \mathrm{O} \rightarrow\left(\mathrm{NH}_{4}\right)_{2} \mathrm{UO}_{2}\left(\mathrm{NO}_{3}\right)_{4} \cdot \mathrm{H}_{2} \mathrm{O} \rightarrow$ $\left(\mathrm{NH}_{4}\right)_{2} \mathrm{UO}_{2}\left(\mathrm{NO}_{3}\right)_{4} \rightarrow \mathrm{NH}_{4} \mathrm{UO}_{2}\left(\mathrm{NO}_{3}\right)_{3} \rightarrow \mathrm{A}-\mathrm{UO}_{3} \rightarrow \gamma-\mathrm{UO}_{3}$ $\rightarrow \mathrm{U}_{3} \mathrm{O}_{8}, \mathrm{NH}_{4} \mathrm{UO}_{2}\left(\mathrm{NO}_{3}\right)_{3} \rightarrow \mathrm{A}-\mathrm{UO}_{3} \rightarrow \alpha-\mathrm{UO}_{3} \rightarrow \mathrm{U}_{3} \mathrm{O}_{8}$; under an air atmosphere: $\left(\mathrm{NH}_{4}\right)_{2} \mathrm{UO}_{2}\left(\mathrm{NO}_{3}\right)_{4} \cdot 2 \mathrm{H}_{2} \mathrm{O} \rightarrow\left(\mathrm{NH}_{4}\right)_{2}$ $\mathrm{UO}_{2}\left(\mathrm{NO}_{3}\right)_{4} \cdot \mathrm{H}_{2} \mathrm{O} \rightarrow\left(\mathrm{NH}_{4}\right)_{2} \mathrm{UO}_{2}\left(\mathrm{NO}_{3}\right)_{4} \rightarrow \mathrm{NH}_{4} \mathrm{UO}_{2}\left(\mathrm{NO}_{3}\right)_{3}$

$\rightarrow \mathrm{A}-\mathrm{UO}_{3} \rightarrow \gamma-\mathrm{UO}_{3} \rightarrow \mathrm{U}_{3} \mathrm{O}_{8}, \mathrm{NH}_{4} \mathrm{UO}_{2}\left(\mathrm{NO}_{3}\right)_{3} \rightarrow \mathrm{A}-\mathrm{UO}_{3}$ $\rightarrow \alpha-\mathrm{UO}_{3} \rightarrow \mathrm{U}_{3} \mathrm{O}_{8}$; and under a hydrogen atmosphere: $\left(\mathrm{NH}_{4}\right)_{2} \mathrm{UO}_{2}\left(\mathrm{NO}_{3}\right)_{4} \cdot 2 \mathrm{H}_{2} \mathrm{O} \rightarrow\left(\mathrm{NH}_{4}\right)_{2} \mathrm{UO}_{2}\left(\mathrm{NO}_{3}\right)_{4} \cdot \mathrm{H}_{2} \mathrm{O} \rightarrow\left(\mathrm{NH}_{4}\right)_{2}$ $\mathrm{UO}_{2}\left(\mathrm{NO}_{3}\right)_{4} \rightarrow \mathrm{NH}_{4} \mathrm{UO}_{2}\left(\mathrm{NO}_{3}\right)_{3} \rightarrow \mathrm{A}-\mathrm{UO}_{3} \rightarrow \gamma-\mathrm{UO}_{3} \rightarrow$
\end{abstract}

B. H. Kim $(\bowtie) \cdot$ Y. B. Lee

Department of Fast Reactor Technology Development, Korea Atomic Energy Research Institute, 150 Deokjin-dong, Daejeon 305-353, Korea

e-mail: bhkim1@kaeri.re.kr

M. A. Prelas - T. K. Ghosh

Nuclear Science and Engineering Institute, University of Missouri, Columbia, MO, USA
$\alpha-\mathrm{U}_{3} \mathrm{O}_{8} \rightarrow \mathrm{UO}_{2}, \quad \mathrm{NH}_{4} \quad \mathrm{UO}_{2}\left(\mathrm{NO}_{3}\right)_{3} \rightarrow \mathrm{A}-\mathrm{UO}_{3} \rightarrow \beta-\mathrm{UO}_{3}$ $\rightarrow \alpha-\mathrm{U}_{3} \mathrm{O}_{8} \rightarrow \mathrm{UO}_{2}$.

Keywords Ammonium uranyl nitrate - Thermal decomposition $\cdot$ Modified direct denitration

\section{Introduction}

Ammonium uranyl nitrate (AUN) is an important intermediate product during conversion of uranyl nitrate $\left[\mathrm{UO}_{2}\left(\mathrm{NO}_{3}\right)_{2}\right]$ solution to $\mathrm{UO}_{2}$ powder for the fabrication of nuclear fuels, the so-called modified direct denitration (MDD) process. Many conversion processes have been developed, such as, ammonium uranyl carbonate (AUC), ammonium diuranate (ADU), and an integrated dry route (IDR). Each process has its merits and demerits. In comparison with other processes, the MDD process offers the greatest potential for cost reduction and good product quality for the production of $\mathrm{UO}_{2}$ powder.

The modified direct denitration process involves the thermal decomposition of AUN double salts, which are prepared from a mixture consisting of a $\mathrm{UO}_{2}\left(\mathrm{NO}_{3}\right)_{2}$ solution and $\mathrm{NH}_{4} \mathrm{NO}_{3}$. The physical and chemical properties of an oxide powder depend upon its thermal treatment. Also, the sintering behavior of $\mathrm{UO}_{2}$ powder can be related to its powder characteristics and processing parameters. It has been observed that the presence of $\mathrm{NH}_{4} \mathrm{NO}_{3}$ in a $\mathrm{UO}_{2}\left(\mathrm{NO}_{3}\right)_{2}$ feed solution prior to a thermal denitration greatly improved the sintering properties of $\mathrm{UO}_{2}$ powder [1].

Three double salts are known for the $\mathrm{UO}_{2}\left(\mathrm{NO}_{3}\right)_{2}-$ $\mathrm{NH}_{4} \mathrm{NO}_{3}-\mathrm{H}_{2} \mathrm{O}$ system, but there have been only a few studies done on thermal decomposition of these salts. Laboratory scale denitration tests showed that $\mathrm{NH}_{4} \mathrm{UO}_{2}\left(\mathrm{NO}_{3}\right)_{3}$ decomposes without melting, and thus does not form a dough stage 
similar to that encountered during a denitration. Also, $\mathrm{UO}_{2}$ produced from $\mathrm{NH}_{4} \mathrm{UO}_{2}\left(\mathrm{NO}_{3}\right)_{3}$ in these tests appeared to be more active than a corresponding oxide produced from $\mathrm{UO}_{2}\left(\mathrm{NO}_{3}\right)_{2}$ solution. It was also reported that $\mathrm{NH}_{4} \mathrm{UO}_{2}\left(\mathrm{NO}_{3}\right)_{3}$ decomposes without melting at $270-300{ }^{\circ} \mathrm{C}$ to give $\gamma-\mathrm{UO}_{3}$ powder of an average size of approximately $3 \mu \mathrm{m}$, with good ceramic properties for its fabrication into $\mathrm{UO}_{2}$ nuclear fuel pellets [2].

In the conversion of AUN to uranium oxides, the characteristic of the resulting powder particles depends upon the AUN preparation process and also upon the thermal decomposition procedures. ADU decomposes first and then leads to $\mathrm{UO}_{3}$. Amorphous uranium trioxide $\left(\mathrm{A}-\mathrm{UO}_{3}\right)$ is mainly formed in the absence of ammonium and nitrate ions, whereas deamination of the retained ammonia leads to $\beta$-UO $\mathrm{UO}_{3}$ [3]. Meanwhile, AUC decomposes at around $190{ }^{\circ} \mathrm{C}$, giving off $\mathrm{CO}_{2}, \mathrm{NH}_{3}$, and $\mathrm{H}_{2} \mathrm{O}$ with the formation of an amorphous phase. In a $\mathrm{N}_{2}$, Ar, or $\mathrm{CO}_{2}$ atmosphere, the amorphous phase crystallizes to $\alpha$ $\mathrm{UO}_{3}$ before decomposing to $\mathrm{U}_{3} \mathrm{O}_{8}$ [4]. Various reports have been published on thermal analysis studies of the reactions occurring during a decomposition of AUC and ADU. However, few studies on the thermal decomposition of AUN can be found in the literature. Therefore, the objective of this study is to investigate the reaction pathways during a thermal decomposition and reduction of AUN to achieve a better knowledge of the influence of an AUN preparation process and thermal decomposition procedures on uranium oxides under a nitrogen, air, or hydrogen atmosphere.

\section{Experimental}

The $\mathrm{UO}_{2}\left(\mathrm{NO}_{3}\right)_{2} \cdot 6 \mathrm{H}_{2} \mathrm{O}$ and $\mathrm{NH}_{4} \mathrm{NO}_{3}$ solutions were prepared using various mole ratios of $\mathrm{NH}_{4}{ }^{+} / \mathrm{U}$. $\left(\mathrm{NH}_{4}\right)_{2} \mathrm{UO}_{2}$ $\left(\mathrm{NO}_{3}\right)_{4} \cdot 2 \mathrm{H}_{2} \mathrm{O}$ was resulted when the $\mathrm{pH}$ of the reaction solution was 2.58 and the mole ratio of $\mathrm{NH}_{4}^{+} / \mathrm{U}$ was 2.14 . And $\mathrm{NH}_{4} \mathrm{UO}_{2} \mathrm{NO}_{3}$ was resulted when the $\mathrm{pH}$ of the reaction solution was 2.01 and the mole ratio of $\mathrm{NH}_{4}{ }^{+} / \mathrm{U}$ was 1.07 . The volume of both $\mathrm{UO}_{2}\left(\mathrm{NO}_{3}\right)_{2} \cdot 6 \mathrm{H}_{2} \mathrm{O}$ and $\mathrm{NH}_{4} \mathrm{NO}_{3}$ solutions were $50 \mathrm{~mL}$. The mixed reaction of these two solutions was performed in a heating mantle where the temperature could be automatically controlled. The reaction temperature was maintained at $90{ }^{\circ} \mathrm{C}$. After the reaction had progressed to a point which a precipitate was generated, the heating was stopped and the precipitated solid was filtered. The precipitate remaining on the filter paper was then left at room temperature to dry. As a result, a primary sample was prepared. The primary sample contained unreacted $\mathrm{UO}_{2}\left(\mathrm{NO}_{3}\right)_{2} \cdot 6 \mathrm{H}_{2} \mathrm{O}$ and $\mathrm{NH}_{4} \mathrm{NO}_{3}$ as impurities. To eliminate these impurities, the primary sample was recrystallized. The recrystallization was performed by dissolving the primary sample in distilled water at $40{ }^{\circ} \mathrm{C}$, and then cooling it down to room temperature. The crystals acquired through the recrystallization were referred to as the secondary sample. The $\mathrm{pH}$ of the mixed solution was controlled by adding $\mathrm{UO}_{3}$ or concentrated nitric acid to the mixed solution. Next the synthesis of AUN was carried out. When the $\mathrm{UO}_{3}$ was added to that, it was dissolved at a temperature of $30{ }^{\circ} \mathrm{C}$. To eliminate any undissolved $\mathrm{UO}_{3}$ from the reaction solution, it was filtered, and the filtrate was used as the reaction solution for AUN synthesis. The characterization of synthesized AUN was reported in previous studies [5].

To analyze the thermal decomposition and reduction pathways of each AUN, the respective thermal decomposition and reduction temperature must be determined beforehand to identify any intermediate phase produced from each reaction stage. For this purpose, a thermogravimetric (TG)/differential thermal analysis (DTA) experiment was carried out in various atmospherics, which were $100 \%$ nitrogen, air, and hydrogen gas. The flow rate for each gas was $50 \mathrm{~mL} / \mathrm{min}$, the heating rate was $5{ }^{\circ} \mathrm{C} /$ $\mathrm{min}$, and the temperature was varied from room temperature to $800{ }^{\circ} \mathrm{C}$. About $8 \mathrm{mg}$ of sample was used in each run. Each reaction stage was identified on the basis of DTA results, and the temperature for the intermediate phase was determined. Samples used to acquire the intermediate phase were obtained by heating each AUN sample in the thermal analyzer up to the temperature as determined from the DTA results. About $40 \mathrm{mg}$ of AUN was thermally decomposed and reduced in the thermal analyzer to produce the samples for use in the analyzer in order to identify the intermediate phases. The intermediate reaction phases were determined and identified by TG analysis and X-ray diffraction. The characteristic analyzes of the intermediate phases and sample preparations were performed by a TGDTA unit (TA Instrument, Simultaneous SDT 2960). The $\mathrm{X}$-ray diffraction analysis was performed at room temperature at a scan speed of $0.4 \% \mathrm{~min}$ and by varying the value of $2 \theta$ from $10^{\circ}$ to $70^{\circ}$. The target was $\mathrm{Cu}$, and one slit was used for the divergence and scattering (Rigaku Max/3D).

\section{Results and discussion}

\section{DTA analysis}

The DTA results from the thermal decomposition of $\left(\mathrm{NH}_{4}\right)_{2} \mathrm{UO}_{2}\left(\mathrm{NO}_{3}\right)_{4} \cdot 2 \mathrm{H}_{2} \mathrm{O}$ as manufactured under a nitrogen, air, and hydrogen atmosphere are shown in Fig. 1. The reaction under the nitrogen atmosphere started at around $50{ }^{\circ} \mathrm{C}$ with a dehydration of the hydrate, which is an endothermic reaction. Endothermic peaks, which seemed to be a phase change of $\mathrm{NH}_{4} \mathrm{NO}_{3}$, were due to the presence of extremely small amount of impurities. These peaks 


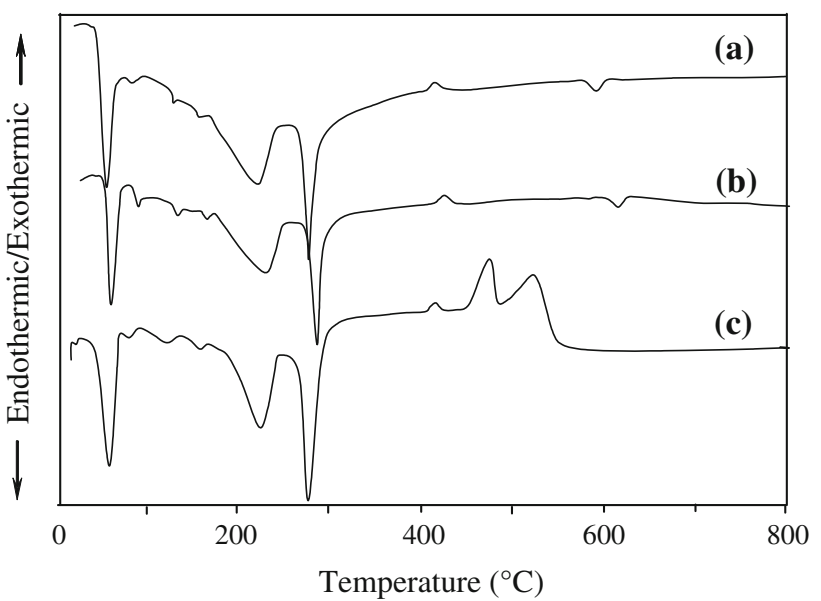

Fig. 1 DTA curves for $\left(\mathrm{NH}_{4}\right)_{2} \mathrm{UO}_{2}\left(\mathrm{NO}_{3}\right)_{4} \cdot 2 \mathrm{H}_{2} \mathrm{O}$ in $\mathbf{a ~} \mathrm{N}_{2}$, b Air, and c $\mathrm{H}_{2}$ atmosphere

appeared around 84,130 , and $155^{\circ} \mathrm{C}$. An endothermic peak as a result of the first thermal decomposition of $\left(\mathrm{NH}_{4}\right)_{2} \mathrm{UO}_{2}\left(\mathrm{NO}_{3}\right)_{4} \cdot 2 \mathrm{H}_{2} \mathrm{O}$ into $\mathrm{NH}_{4} \mathrm{NO}_{3}$ appeared within a temperature range of 168 to $240{ }^{\circ} \mathrm{C}$. A second endothermic that was due to the second thermal decomposition of $\mathrm{NH}_{4} \mathrm{NO}_{3}$ appeared in the temperature range of 268 to $307^{\circ} \mathrm{C}$. After the second endothermic peak continued, a weak exothermic reaction took place around $400{ }^{\circ} \mathrm{C}$. This reaction continued for a while, and then ended as an endothermic reaction that took place at $579{ }^{\circ} \mathrm{C}$.

The thermal decomposition under the air atmosphere showed a different trend. $\mathrm{NH}_{4} \mathrm{UO}_{2}\left(\mathrm{NO}_{3}\right)_{3}$ was thermally decomposed to $\mathrm{UO}_{3}$ at around $275{ }^{\circ} \mathrm{C}$, which was about $7{ }^{\circ} \mathrm{C}$ higher than the corresponding temperature under the nitrogen atmosphere. An exothermic reaction was observed at a temperature slightly higher than $400{ }^{\circ} \mathrm{C}$. However an endothermic reaction took place at around $599{ }^{\circ} \mathrm{C}$. It is assumed that such a difference in the reaction temperature between an air and a nitrogen atmosphere was due to the different activation energy that was dependent on the atmospheric under which the decomposition was carried out. Also, it has been reported that if the composition of a compound is different or an impurity is present, the peak of the DTA curve moves toward a higher temperature [4].

Under a hydrogen atmosphere, the thermal decomposition was followed by a reduction reaction. First, the dehydration of $\left(\mathrm{NH}_{4}\right)_{2} \mathrm{UO}_{2}\left(\mathrm{NO}_{3}\right)_{4} \cdot 2 \mathrm{H}_{2} \mathrm{O}$ occurred, and the thermal decomposition of $\mathrm{NH}_{4} \mathrm{NO}_{3}$ then took place, which had the same trend as that under nitrogen and air atmospheres. However, both the temperature at which the thermal decomposition took place and the maximum peak temperature shifted toward a lower temperature. Like the exothermic peak under the nitrogen and air atmospheres, the exothermic peak appeared at around $400{ }^{\circ} \mathrm{C}$. However, the subsequent reactions were different from those under

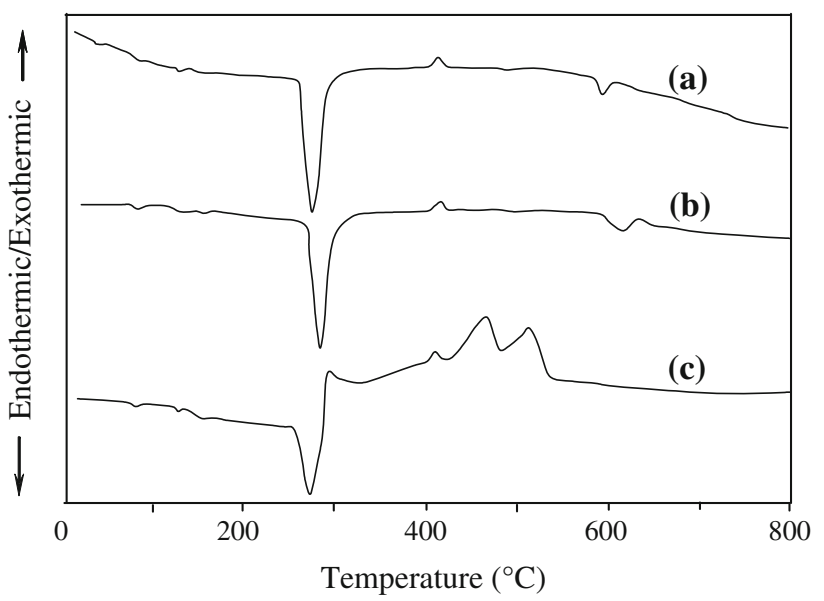

Fig. 2 DTA curves for $\mathrm{NH}_{4} \mathrm{UO}_{2}\left(\mathrm{NO}_{3}\right)_{3}$ in a $\mathrm{N}_{2}$, b air, and $\mathbf{c} \mathrm{H}_{2}$ atmosphere

the nitrogen and air atmospheres due to the reduction by hydrogen, which caused the appearance of two different exothermic peaks. An exothermic reaction took place at $440{ }^{\circ} \mathrm{C}$, then shortly after another exothermic reaction started at around $590{ }^{\circ} \mathrm{C}$. Halldahl and Nygren [4] also observed a similar phenomenon, the DTA curves for decomposition of $\left(\mathrm{NH}_{4}\right)_{2} \mathrm{UO}_{2}\left(\mathrm{NO}_{3}\right)_{4} \cdot 2 \mathrm{H}_{2} \mathrm{O}$ were dependent upon the atmospheric gas used during the decomposition. Halldahl also reported that the maximum peak temperature when AUC was thermally decomposed into $\mathrm{UO}_{3}$ under a nitrogen, air, and hydrogen atmosphere was 195, 198, and $185^{\circ} \mathrm{C}$, respectively. The thermal decomposition temperature became lower in the following order: hydrogen $<$ nitrogen $<$ air. This result is similar to the result observed in the current study, where the maximum peak temperature appeared when $\left(\mathrm{NH}_{4}\right)_{2} \mathrm{UO}_{2}\left(\mathrm{NO}_{3}\right)_{4} \cdot 2 \mathrm{H}_{2} \mathrm{O}$ was decomposed into $\mathrm{UO}_{3}$.

The DTA results for the thermal decomposition and reduction of $\mathrm{NH}_{4} \mathrm{UO}_{2}\left(\mathrm{NO}_{3}\right)_{3}$ under different atmospheric gases are shown in Fig. 2. The results were found to be very similar to the DTA results of the thermal decomposition and reduction of $\left(\mathrm{NH}_{4}\right)_{2} \mathrm{UO}_{2}\left(\mathrm{NO}_{3}\right)_{4} \cdot 2 \mathrm{H}_{2} \mathrm{O}$. Plus, in the case of $\left(\mathrm{NH}_{4}\right)_{2} \mathrm{UO}_{2}\left(\mathrm{NO}_{3}\right)_{4} \cdot 2 \mathrm{H}_{2} \mathrm{O}$, the endothermic peaks appeared around 84,130 , and $155^{\circ} \mathrm{C}$ due to a phase change of $\mathrm{NH}_{4} \mathrm{NO}_{3}$. It may be noted that in the case of $\mathrm{NH}_{4} \mathrm{UO}_{2}\left(\mathrm{NO}_{3}\right)_{3}$, such peaks were very weak.

The endothermic peak resulting from the thermal decomposition of $\mathrm{NH}_{4} \mathrm{NO}_{3}$, which was the first reaction under a nitrogen atmosphere, appeared between 266 and $305{ }^{\circ} \mathrm{C}$, and a weak exothermic reaction then took place at around $400{ }^{\circ} \mathrm{C}$ followed by an endothermic reaction at $578{ }^{\circ} \mathrm{C}$. Also, in air, an endothermic reaction was observed at $277{ }^{\circ} \mathrm{C}$, an exothermic reaction around $400{ }^{\circ} \mathrm{C}$, and two endothermic reactions at around $598^{\circ} \mathrm{C}$. Under a hydrogen atmosphere, one endothermic reaction was observed at 
Table 1 Thermal treatment conditions for the preparation of intermediates decomposed from $\left(\mathrm{NH}_{4}\right)_{2} \mathrm{UO}_{2}\left(\mathrm{NO}_{3}\right)_{4} \cdot 2 \mathrm{H}_{2} \mathrm{O}$ and $\mathrm{NH}_{4} \mathrm{UO}_{2}$ $\left(\mathrm{NO}_{3}\right)_{3}$

Atmosphere Final temperature of thermal treatment for intermediates of $\left(\mathrm{NH}_{4}\right)_{2} \mathrm{UO}_{2}\left(\mathrm{NO}_{3}\right)_{4} \cdot 2 \mathrm{H}_{2} \mathrm{O}$ and $\mathrm{NH}_{4} \mathrm{UO}_{2}\left(\mathrm{NO}_{3}\right)_{3}\left({ }^{\circ} \mathrm{C}\right)$

\begin{tabular}{lllll}
\hline $\mathrm{N}_{2}$ & 390 & 480 & & 800 \\
Air & 390 & 480 & & 800 \\
$\mathrm{H}_{2}$ & 390 & 430 & 480 & 600 \\
\hline
\end{tabular}

$270{ }^{\circ} \mathrm{C}$, and three exothermic reactions were then observed at around 400,441 , and $590{ }^{\circ} \mathrm{C}$.

Preparation of samples for analysis of intermediate phases

The temperatures at which the endothermic and exothermic reactions started and ended, as shown in the DTA curves, were used to determine intermediate phases during thermal decomposition of $\left(\mathrm{NH}_{4}\right)_{2} \mathrm{UO}_{2}\left(\mathrm{NO}_{3}\right)_{4} \cdot 2 \mathrm{H}_{2} \mathrm{O}$ and $\mathrm{NH}_{4} \mathrm{UO}_{2}$ $\left(\mathrm{NO}_{3}\right)_{3}$ and during their reduction. These intermediate phases are shown in Table 1. The samples for acquiring the intermediate phases were prepared under the respective atmospheres by decomposing $\left(\mathrm{NH}_{4}\right)_{2} \mathrm{UO}_{2}\left(\mathrm{NO}_{3}\right)_{4} \cdot 2 \mathrm{H}_{2} \mathrm{O}$ and $\mathrm{NH}_{4} \mathrm{UO}_{2}\left(\mathrm{NO}_{3}\right)_{3}$ thermally at 390,480 , and $800{ }^{\circ} \mathrm{C}$, under the nitrogen and air atmospheres, and at 390, 430, 480, and $600{ }^{\circ} \mathrm{C}$ under a hydrogen atmosphere. The samples were further reduced in a thermal analyzer and cooled down to room temperature. The X-ray diffraction analysis of each intermediate phase was performed to gain a better understanding of the intermediate phases.

X-ray diffraction analysis of intermediate phases obtained from AUN

Under a nitrogen atmosphere $\left(\mathrm{NH}_{4}\right)_{2} \mathrm{UO}_{2}\left(\mathrm{NO}_{3}\right)_{4}$ and $\mathrm{NH}_{4} \mathrm{UO}_{2}\left(\mathrm{NO}_{3}\right)_{3}$ were produced from $\left(\mathrm{NH}_{4}\right)_{2} \mathrm{UO}_{2}\left(\mathrm{NO}_{3}\right)_{4}$. $2 \mathrm{H}_{2} \mathrm{O}$, while $\mathrm{NH}_{4} \mathrm{NO}_{3}$ was thermally decomposed. A new intermediate phase was produced from $\mathrm{NH}_{4} \mathrm{UO}_{2}\left(\mathrm{NO}_{3}\right)_{3}$ through an endothermic reaction. As shown in Fig. 3b, the structure of $\mathrm{NH}_{4} \mathrm{UO}_{2}\left(\mathrm{NO}_{3}\right)_{3}$ disappeared completely at a thermal decomposition temperature of $390{ }^{\circ} \mathrm{C}$, and amorphous $\mathrm{UO}_{3}$, a new uranium oxide was formed. In addition, it was also found that in the intermediate phase, amorphous $\mathrm{UO}_{3}$ was subsequently transformed into $\gamma-\mathrm{UO}_{3}$ with a crystal structure at $480{ }^{\circ} \mathrm{C}$ (See Fig. 3c). The $\gamma-\mathrm{UO}_{3}$ subsequently transformed into $\mathrm{U}_{3} \mathrm{O}_{8}$ by a phase change through a weak endothermic reaction at a temperature of $800{ }^{\circ} \mathrm{C}$ (See Fig. 3d).

The intermediate phase obtained after thermal treatment of $\left(\mathrm{NH}_{4}\right)_{2} \mathrm{UO}_{2}\left(\mathrm{NO}_{3}\right)_{4} \cdot 2 \mathrm{H}_{2} \mathrm{O}$ under the air atmosphere appeared to be the same as that obtained under a nitrogen

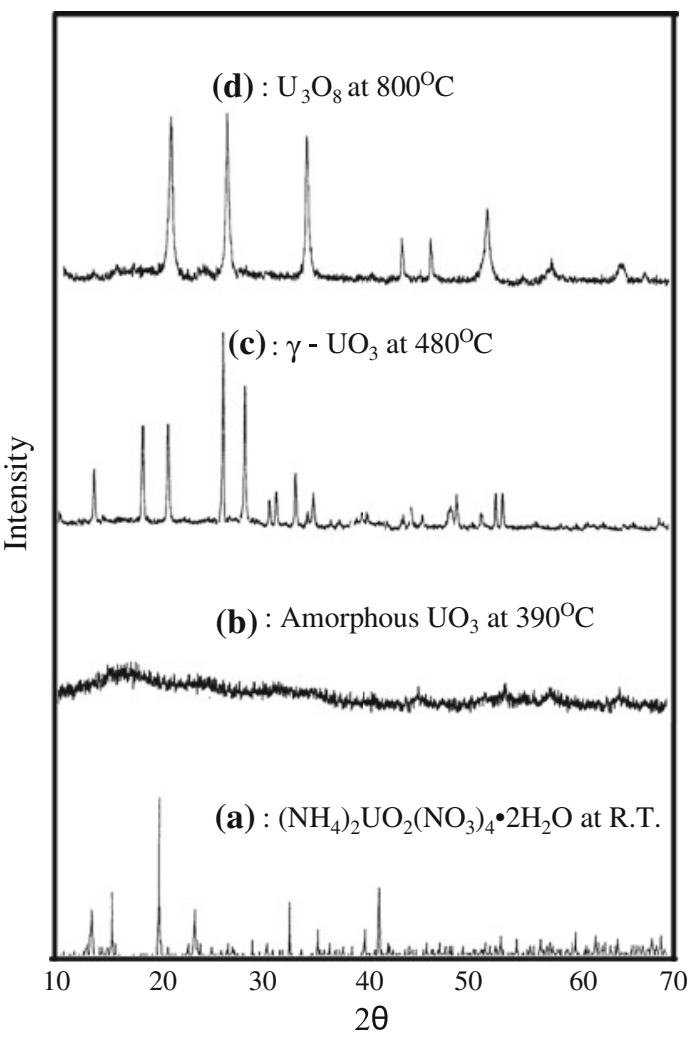

Fig. 3 X-ray diffraction patterns of intermediates produced from $\left(\mathrm{NH}_{4}\right)_{2} \mathrm{UO}_{2}\left(\mathrm{NO}_{3}\right)_{4} \cdot 2 \mathrm{H}_{2} \mathrm{O}$ in $\mathrm{N}_{2}$ atmosphere

atmosphere. This is shown in Fig. 4. However, as identified in the DTA results, under an air atmosphere, the intermediate phase was produced at a higher temperature than that at a nitrogen atmosphere.

Under a hydrogen atmosphere $\left(\mathrm{NH}_{4}\right)_{2} \mathrm{UO}_{2}\left(\mathrm{NO}_{3}\right)_{4} \cdot 2 \mathrm{H}_{2} \mathrm{O}$ produced a different intermediate phase through a thermal decomposition and reduction compared to the phase observed when decomposed under nitrogen and air atmospheres. The uranium oxide produced at a temperature of $390{ }^{\circ} \mathrm{C}$ under a hydrogen atmosphere was amorphous $\mathrm{UO}_{3}$ as was the case under nitrogen and air atmospheres (See Fig. 5b), however, amorphous $\mathrm{UO}_{3}$ was crystallized at $430{ }^{\circ} \mathrm{C}$ along with the phase change from $\mathrm{UO}_{3}$ to $\gamma-\mathrm{UO}_{3}$ (See Fig. 5c). Furthermore, $\gamma-\mathrm{UO}_{3}$, which went through an exothermic reaction at $430{ }^{\circ} \mathrm{C}$, was transformed into $\alpha-\mathrm{U}_{3} \mathrm{O}_{8}$ by a phase change at $490{ }^{\circ} \mathrm{C}$ (See Fig. 5 d), and $\alpha-\mathrm{U}_{3} \mathrm{O}_{8}$ was finally reduced to $\mathrm{UO}_{2}$ at $600{ }^{\circ} \mathrm{C}$ (See Fig. 5e).

The DTA results, as shown in Fig. 1 indicated that the temperature at which $\mathrm{UO}_{3}$ was reduced to $\alpha-\mathrm{U}_{3} \mathrm{O}_{8}$ under a hydrogen atmosphere was lower than the temperature at which $\mathrm{UO}_{3}$ was reduced to $\mathrm{U}_{3} \mathrm{O}_{8}$ under an air atmosphere. When $\left(\mathrm{NH}_{4}\right)_{2} \mathrm{UO}_{2}\left(\mathrm{NO}_{3}\right)_{4} \cdot 2 \mathrm{H}_{2} \mathrm{O}$ was thermally decomposed to $\mathrm{UO}_{3}, \mathrm{NH}_{4}^{+}$, as a residual substance, was included in the $\mathrm{UO}_{3}$ matrix. Therefore, as the temperature increased, the ammonia contained in the residual substance was released and further oxidized under an air atmosphere so that the 


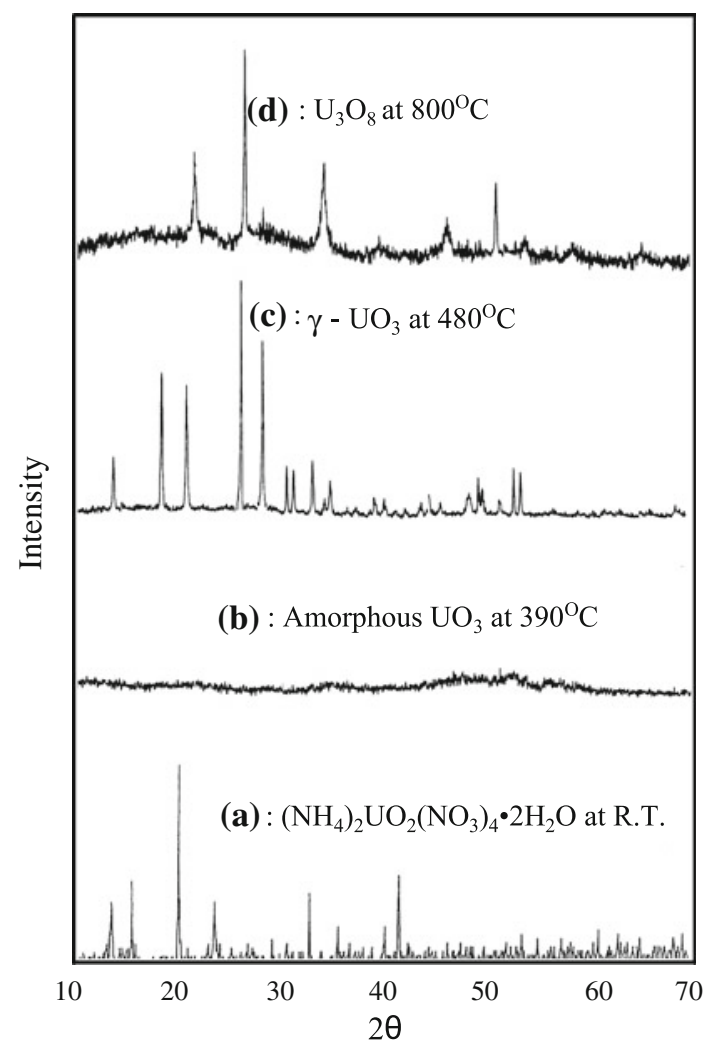

Fig. 4 X-ray diffraction patterns of intermediates from $\left(\mathrm{NH}_{4}\right)_{2} \mathrm{UO}_{2}$ $\left(\mathrm{NO}_{3}\right)_{4} \cdot 2 \mathrm{H}_{2} \mathrm{O}$ in air atmosphere

auto reduction from $\mathrm{UO}_{3}$ to $\mathrm{U}_{3} \mathrm{O}_{8}$ was suppressed [6]. As such, it would appear that the production of $\mathrm{U}_{3} \mathrm{O}_{8}$ from $\mathrm{UO}_{3}$ took place at a lower temperature under a hydrogen atmosphere. Generally, the reduction from $\mathrm{UO}_{3}$ to $\mathrm{U}_{3} \mathrm{O}_{8}$ through an auto reduction is as follows;

$3 \mathrm{UO}_{3} \rightarrow \mathrm{U}_{3} \mathrm{O}_{8}+1 / 2 \mathrm{O}_{2}$.

It is hypothesized that in hydrogen atmosphere, hydrogen was adsorbed on to the matrix and reacted with oxygen ions and then diffused out of the $\mathrm{UO}_{3}$ matrix to produce $\mathrm{H}_{2} \mathrm{O}$. The produced $\mathrm{H}_{2} \mathrm{O}$ desorbed from the $\mathrm{UO}_{3}$ matrix surface, and at the same time, oxygen present in the $\mathrm{UO}_{3}$ rapidly diffused onto the $\mathrm{UO}_{3}$ matrix. This resulted in a fast reduction rate from $\mathrm{UO}_{3}$ to $\mathrm{U}_{3} \mathrm{O}_{8}$. Meanwhile, in air atmosphere, the thermal decomposition rate of $\mathrm{UO}_{3}$ to $\mathrm{U}_{3} \mathrm{O}_{8}$ was slow, because the oxygen present in the $\mathrm{UO}_{3}$ was prevented from being diffused onto the $\mathrm{UO}_{3}$ matrix.

As shown in Fig. 6, in the case of $\mathrm{NH}_{4} \mathrm{UO}_{2}\left(\mathrm{NO}_{3}\right)_{3}$, under a nitrogen atmosphere, amorphous $\mathrm{UO}_{3}$ was produced at $390{ }^{\circ} \mathrm{C}$, However, decomposition $\left(\mathrm{NH}_{4}\right)_{2} \mathrm{UO}_{2}\left(\mathrm{NO}_{3}\right)_{4} \cdot 2 \mathrm{H}_{2} \mathrm{O}$ (See Fig. 6b) resulted in $\alpha-\mathrm{UO}_{3}$ at $480{ }^{\circ} \mathrm{C}$ (See Fig. 6c). When comparing this phenomenon with the one in which $\left(\mathrm{NH}_{4}\right)_{2} \mathrm{UO}_{2}\left(\mathrm{NO}_{3}\right)_{4} \cdot 2 \mathrm{H}_{2} \mathrm{O}$ produced $\gamma-\mathrm{UO}_{3}$ at a temperature of $480{ }^{\circ} \mathrm{C}$, it suggests that $\mathrm{NH}_{4} \mathrm{UO}_{2}\left(\mathrm{NO}_{3}\right)_{3}$ was thermally decomposed through a different phase change route

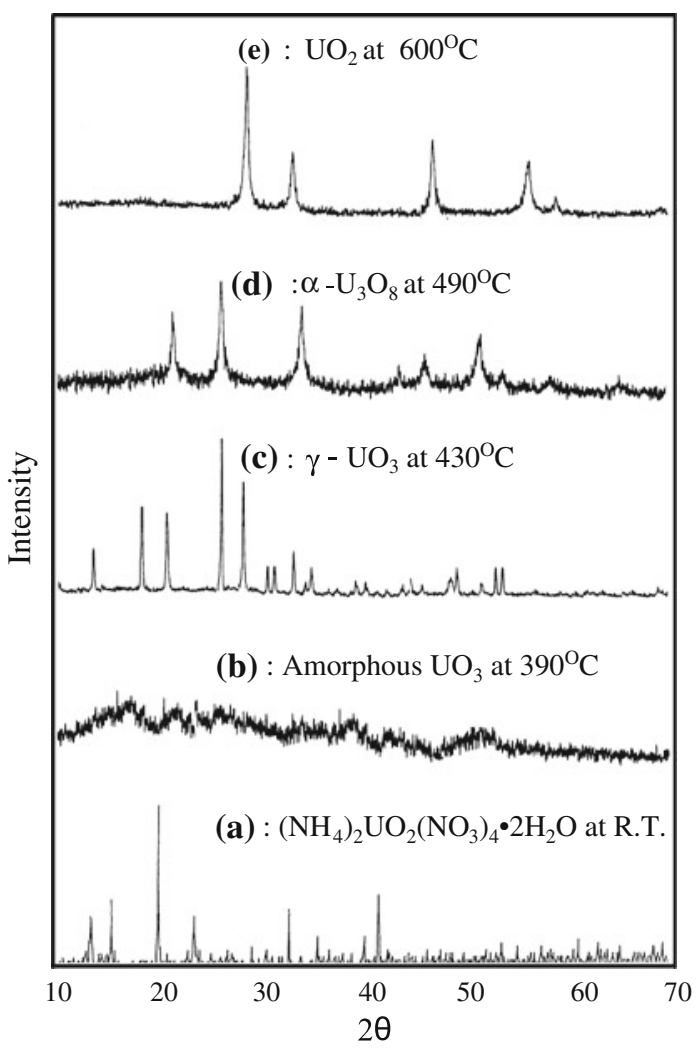

Fig. $5 \mathrm{X}$-ray diffraction patterns of intermediates produced from $\left(\mathrm{NH}_{4}\right)_{2} \mathrm{UO}_{2}\left(\mathrm{NO}_{3}\right)_{4} \cdot 2 \mathrm{H}_{2} \mathrm{O}$ in $\mathrm{H}_{2}$ atmosphere

compared to $\left(\mathrm{NH}_{4}\right)_{2} \mathrm{UO}_{2}\left(\mathrm{NO}_{3}\right)_{4} \cdot 2 \mathrm{H}_{2} \mathrm{O}$ decomposition route. Subsequently, the $\alpha-\mathrm{UO}_{3}$ phase, which went through an endothermic reaction at $540{ }^{\circ} \mathrm{C}$, changed into $\alpha-\mathrm{U}_{3} \mathrm{O}_{8}$ with a crystal structure at a temperature of $800{ }^{\circ} \mathrm{C}$ (See Fig. 6d). As shown in Fig. 7, the thermal decomposition process under an air atmosphere was found to be the same as that under a nitrogen atmosphere.

As can be seen from Fig. 8, the thermal decomposition and reduction of $\mathrm{NH}_{4} \mathrm{UO}_{2}\left(\mathrm{NO}_{3}\right)_{3}$ under a hydrogen atmosphere resulted in a final product of $\mathrm{UO}_{2}$ (See Fig. 8e) with a crystal structure through a series of phase changes to amorphous $\mathrm{UO}_{3}$ (See Fig. 8b), $\beta$ - $\mathrm{UO}_{3}$ (See Fig. 8c), and $\mathrm{U}_{3} \mathrm{O}_{8}$ (See Fig. 8d). In the case of $\mathrm{NH}_{4} \mathrm{UO}_{2}\left(\mathrm{NO}_{3}\right)_{3}$, when amorphous $\mathrm{UO}_{3}$ crystallized, $\beta$ - $\mathrm{UO}_{3}$ was produced in the intermediate phase, whereas in the case of $\left(\mathrm{NH}_{4}\right)_{2} \mathrm{UO}_{2}$ $\left(\mathrm{NO}_{3}\right)_{4} \cdot 2 \mathrm{H}_{2} \mathrm{O}, \gamma-\mathrm{UO}_{3}$ was produced in the intermediate phase.

Table 2 shows a comparison of the above $\mathrm{X}$-ray diffraction analysis results and thermal analysis results between ADU and AUC. Specifically, it is worth noting the phase change of $\mathrm{UO}_{3}$ among the intermediate phases of the uranium oxide that are produced during thermal decomposition process of two AUNs. It may be noted that the sinterability of $\mathrm{UO}_{2}$ powder is significantly related to the physical and chemical characteristics of the precursor and 


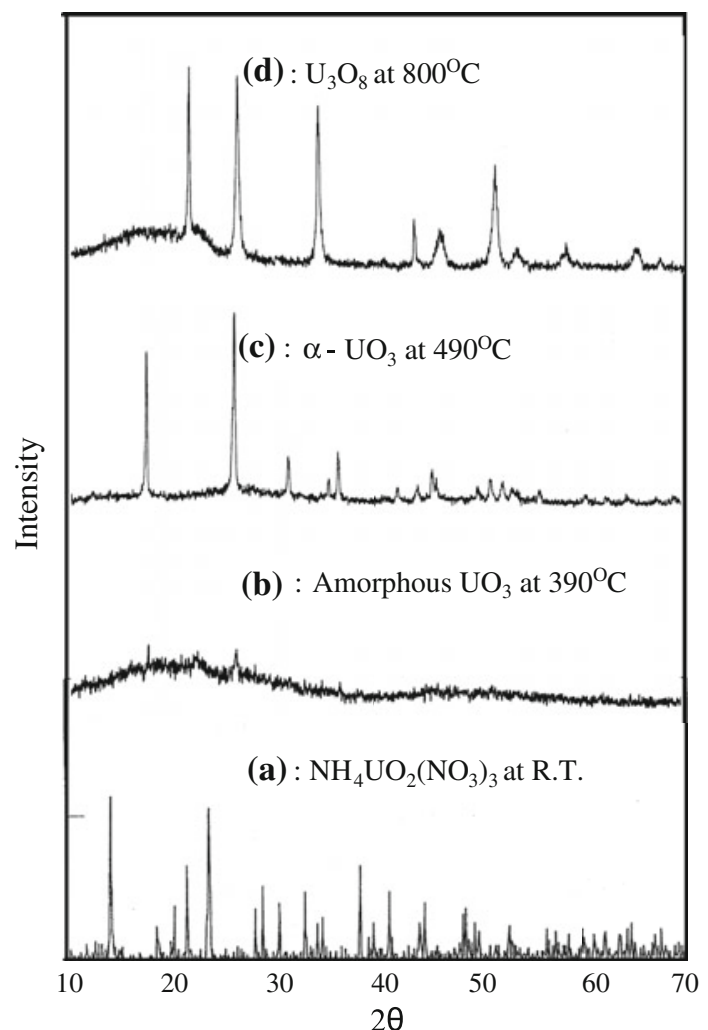

Fig. $6 \mathrm{X}$-ray diffraction patterns of intermediates produced from $\left(\mathrm{NH}_{4}\right) \mathrm{UO}_{2}\left(\mathrm{NO}_{3}\right)_{3}$ in $\mathrm{N}_{2}$ atmosphere

the reaction mechanism of the intermediate phases [7]. In the current study, it was found that $\gamma-\mathrm{UO}_{3}$ was produced as an intermediate product when $\left(\mathrm{NH}_{4}\right)_{2} \mathrm{UO}_{2}\left(\mathrm{NO}_{3}\right)_{4} \cdot 2 \mathrm{H}_{2} \mathrm{O}$ was thermally decomposed irrespective of the atmospheric gas used. However, when $\mathrm{NH}_{4} \mathrm{UO}_{2}\left(\mathrm{NO}_{3}\right)_{3}$ was decomposed, different forms of $\mathrm{UO}_{3}$ were produced depending on the atmosphere under which the decomposition was carried out. Under nitrogen and air atmospheres, $\alpha-\mathrm{UO}_{3}$ was produced, where as $\beta-\mathrm{UO}_{3}$ was resulted while under a hydrogen atmosphere. It appears that starting substance, atmospheric gas, and reaction gas discharge affected the decomposition reaction. The thermal decomposition and reduction processes of AUN have not been studied adequately, and an understanding of various reaction processes of AUN is unavailable. However, various studies with different opinions have been reported in the literature on the reduction ADU and AUC. Woolfrey [8] explained that under a hydrogen atmosphere, ADU can be directly reduced to $\mathrm{UO}_{2}$, under oxygen or nitrogen atmosphere, ADU is transformed into $\mathrm{UO}_{3}$ and $\mathrm{U}_{3} \mathrm{O}_{8}$ through a calcination process, which can then be reduced to $\mathrm{UO}_{2}$ under a hydrogen atmosphere. Cordfunke [9] reported that amorphous $\mathrm{UO}_{3}$ and $\beta-\mathrm{UO}_{3}$ exist in a crystal form during the process of thermal decomposition of ADU. Landspersky [10] and Rodriguez et al. [11] noted that the existence of two forms of $\mathrm{UO}_{3}$ is due to the heating rate during thermal

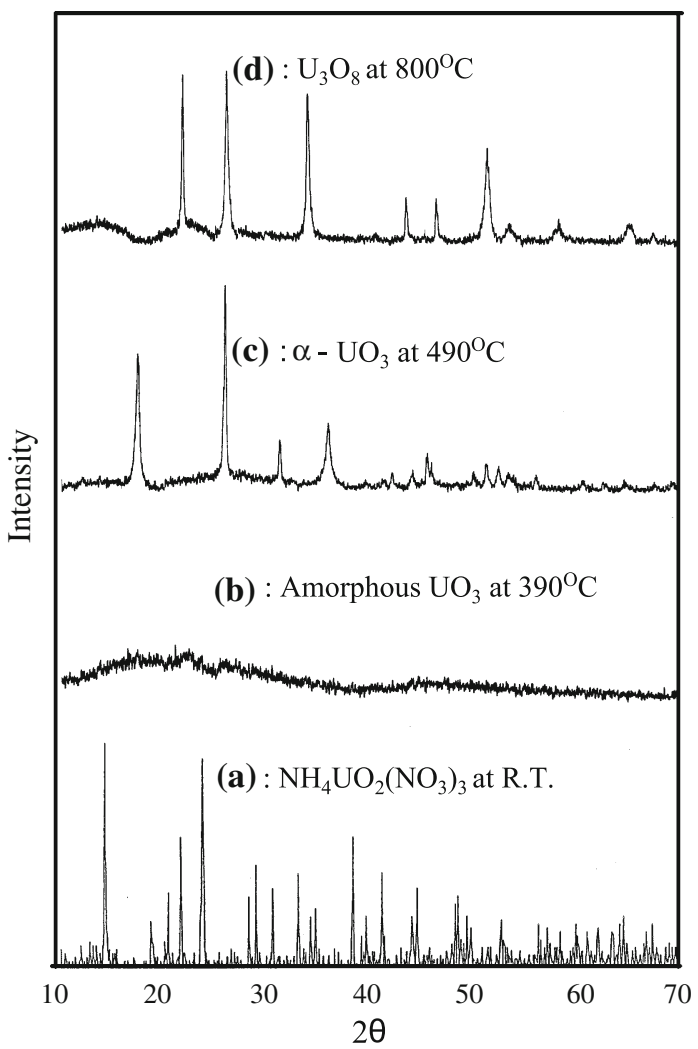

Fig. 7 X-ray diffraction patterns of intermediates produced from $\left(\mathrm{NH}_{4}\right) \mathrm{UO}_{2}\left(\mathrm{NO}_{3}\right)_{3}$ in air atmosphere

decomposition. Landspersky [10] reported that when the heating rate during thermal decomposition is slow $\left(1{ }^{\circ} \mathrm{C} /\right.$ $\min$ ), amorphous $\mathrm{UO}_{3}$ was produced, whereas when the heating rate increases $\left(10{ }^{\circ} \mathrm{C} / \mathrm{min}\right), \beta-\mathrm{UO}_{3}$ is produced. So far, it would seem that the forms of $\mathrm{UO}_{3}$ produced during the process of a thermal decomposition of ADU are mostly amorphous $\mathrm{UO}_{3}$ and $\beta-\mathrm{UO}_{3}$, irrespective of the atmospheric gas used [7]. However, Kim [12] reported that in the case of thermal decomposition of AUC, under an air atmosphere, only amorphous $\mathrm{UO}_{3}$ was produced, while under nitrogen and hydrogen atmospheres, amorphous $\mathrm{UO}_{3}$ and $\beta-\mathrm{UO}_{3}$ are produced. As shown in Table 2, the thermal decomposition and reduction process of AUC depend on the atmospheric gas or starting substance used. In particular, the reaction process differed depending on the two forms of AUN used in this study. In the case of AUN, the starting substance is produced by varying the mole ratio of $\mathrm{NH}_{4}{ }^{+} / \mathrm{U}$, and adding $\mathrm{NH}_{4} \mathrm{NO}_{3}$ as a reactant at a specified time. In the case of $\mathrm{AUC}$, both $\mathrm{NH}_{3}$ and $\mathrm{CO}_{2}$ were used as reactants. In the case of $\mathrm{ADU}$, both $\mathrm{NH}_{4} \mathrm{OH}$ and $\mathrm{NH}_{3}$ are used as reactants. These additives affected the thermal decomposition characteristics of final products.

An analysis of the intermediate phases and reaction characteristics has been discussed for each stage by using the data from DTA and X-ray diffraction analysis. By comparing these results with the TG analysis results, the 


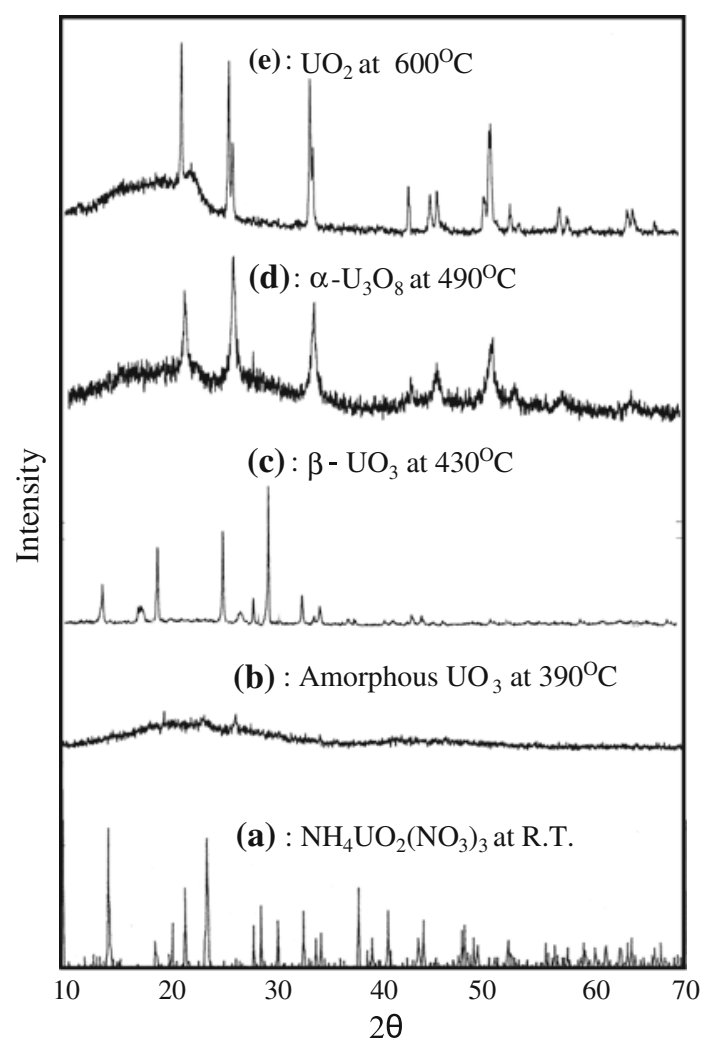

Fig. 8 X-ray diffraction patterns of intermediates produced from $\left(\mathrm{NH}_{4}\right) \mathrm{UO}_{2}\left(\mathrm{NO}_{3}\right)_{3}$ in $\mathrm{H}_{2}$ atmosphere respective thermal decomposition and reduction characteristics of $\left(\mathrm{NH}_{4}\right)_{2} \mathrm{UO}_{2}\left(\mathrm{NO}_{3}\right)_{4} \cdot 2 \mathrm{H}_{2} \mathrm{O}$ and $\mathrm{NH}_{4} \mathrm{UO}_{2}\left(\mathrm{NO}_{3}\right)_{3}$ were also reconfirmed. As already identified, $\mathrm{NH}_{4} \mathrm{UO}_{2}$ $\left(\mathrm{NO}_{3}\right)_{3}$ is decomposed thermally according to the following reaction formula.

$$
\mathrm{NH}_{4} \mathrm{UO}_{2}\left(\mathrm{NO}_{3}\right)_{3} \rightarrow \mathrm{UO}_{3}+\mathrm{N}_{2} \mathrm{O}_{5} \uparrow+\mathrm{N}_{2} \mathrm{O} \uparrow+2 \mathrm{H}_{2} \mathrm{O} \uparrow
$$

The TG curves corresponding to these reactions under different atmospheres are illustrated in Figs. 9 and 10. In the case of $\left(\mathrm{NH}_{4}\right)_{2} \mathrm{UO}_{2}\left(\mathrm{NO}_{3}\right)_{4} \cdot 2 \mathrm{H}_{2} \mathrm{O}$, thermal decomposition of $\mathrm{NH}_{4} \mathrm{UO}_{2}\left(\mathrm{NO}_{3}\right)_{3}$ into $\mathrm{UO}_{3}$ started at 268,275 and $260{ }^{\circ} \mathrm{C}$ under a nitrogen, air, and hydrogen atmosphere, respectively, and ended at about $450{ }^{\circ} \mathrm{C}$ under nitrogen and air atmospheres, and at about $350{ }^{\circ} \mathrm{C}$ under a hydrogen atmosphere. The weight loss was 39.26, 39.16 and 39.05 wt\% under a nitrogen, air, and hydrogen atmosphere, respectively, which was different from the theoretical value of $39.67 \mathrm{wt} \%$. A difference was found for $\mathrm{NH}_{4} \mathrm{UO}_{2}\left(\mathrm{NO}_{3}\right)_{3}$ between the experimental value and the theoretical value. From the $\mathrm{X}$-ray diffraction analysis, it was found that amorphous $\mathrm{UO}_{3}$ was produced at the respective reaction temperatures. The quantitative difference may be due to the existence of a residual substance in the amorphous $\mathrm{UO}_{3}$, mainly due to $\mathrm{NH}_{4}{ }^{+}$or $\mathrm{H}_{2} \mathrm{O}$. Sato et al. [13] reported that amorphous $\mathrm{UO}_{3}$ was produced due to such residual substances. Halldal and Sorensen [14] observed that the decomposition of AUC thermally under a
Table 2 Comparison of the decomposition mechanisms of AU, AUC and AUN with previous results

\begin{tabular}{|c|c|c|}
\hline Researchers & Decomposition mechanism of $\mathrm{AU}$ & Atmosphere \\
\hline Woolfrey [8] & $\begin{array}{l}\mathrm{AU} \mathrm{III} / \mathrm{IV} \rightarrow \mathrm{AU} \text { II } \rightarrow \mathrm{AU} \mathrm{I} \rightarrow \beta-\mathrm{UO}_{3} \rightarrow \\
\mathrm{A}-\mathrm{UO}_{3} \rightarrow \mathrm{U}_{3} \mathrm{O}_{8} / \mathrm{UO}_{2.9} \rightarrow \mathrm{U}_{4} \mathrm{O}_{9} \rightarrow \mathrm{UO}_{2+x}\end{array}$ & $\mathrm{H}_{2}$ \\
\hline \multirow[t]{4}{*}{ Kim [12] } & $\begin{array}{l}\mathrm{AU} \mathrm{II} / \mathrm{III} \rightarrow \mathrm{AU} \mathrm{II} / \mathrm{I} \rightarrow \mathrm{AU} \mathrm{I} \rightarrow \mathrm{A}-\mathrm{UO}_{3} \rightarrow \beta-\mathrm{UO}_{3} \rightarrow \\
\alpha-\mathrm{U}_{3} \mathrm{O}_{8} \rightarrow \mathrm{U}_{4} \mathrm{O}_{9} \rightarrow \mathrm{UO}_{2}\end{array}$ & $\mathrm{H}_{2}$ \\
\hline & $\mathrm{AUC} \rightarrow \mathrm{A}-\mathrm{UO}_{3} \rightarrow \alpha-\mathrm{U}_{3} \mathrm{O}_{8}$ & Air \\
\hline & $\mathrm{AUC} \rightarrow \mathrm{A}-\mathrm{UO}_{3} \rightarrow \alpha-\mathrm{UO}_{3} \rightarrow \alpha-\mathrm{U}_{3} \mathrm{O}_{8}$ & $\mathrm{~N}_{2}$ \\
\hline & $\mathrm{AUC} \rightarrow \mathrm{A}-\mathrm{UO}_{3} \rightarrow \alpha-\mathrm{UO}_{3} \rightarrow \alpha-\mathrm{U}_{3} \mathrm{O}_{8} \rightarrow \mathrm{UO}_{2}$ & $\mathrm{H}_{2}$ \\
\hline Sato [13] & $\mathrm{AU} \rightarrow \mathrm{UO}_{3} \mathrm{NH}_{3} \rightarrow \mathrm{A}-\mathrm{UO}_{3} \rightarrow \beta-\mathrm{UO}_{3} \rightarrow \mathrm{U}_{3} \mathrm{O}_{8}$ & Air \\
\hline Price [15] & $\mathrm{AU} \rightarrow \mathrm{UO}_{3} x \mathrm{NH}_{3} \rightarrow \mathrm{U}_{3} \mathrm{O}_{8} \rightarrow \mathrm{UO}_{2}$ & $\mathrm{H}_{2}$ \\
\hline \multirow[t]{3}{*}{$\begin{array}{r}\text { Current } \\
\text { study }\end{array}$} & $\begin{array}{l}\left(\mathrm{NH}_{4}\right)_{2} \mathrm{UO}_{2}\left(\mathrm{NO}_{3}\right)_{4} \cdot 2 \mathrm{H}_{2} \mathrm{O} \rightarrow\left(\mathrm{NH}_{4}\right)_{2} \mathrm{UO}_{2}\left(\mathrm{NO}_{3}\right)_{4} \cdot \mathrm{H}_{2} \mathrm{O} \\
\rightarrow\left(\mathrm{NH}_{4}\right)_{2} \mathrm{UO}_{2}\left(\mathrm{NO}_{3}\right)_{4} \rightarrow \mathrm{NH}_{4} \mathrm{UO}_{2}\left(\mathrm{NO}_{3}\right)_{3} \rightarrow \mathrm{A}-\mathrm{UO}_{3} \\
\rightarrow \gamma-\mathrm{UO}_{3} \rightarrow \mathrm{U}_{3} \mathrm{O}_{8} \\
\mathrm{NH}_{4} \mathrm{UO}_{2}\left(\mathrm{NO}_{3}\right)_{3} \rightarrow \mathrm{A}-\mathrm{UO}_{3} \rightarrow \alpha-\mathrm{UO}_{3} \rightarrow \mathrm{U}_{3} \mathrm{O}_{8}\end{array}$ & $\mathrm{~N}_{2}$ \\
\hline & $\begin{array}{l}\left(\mathrm{NH}_{4}\right)_{2} \mathrm{UO}_{2}\left(\mathrm{NO}_{3}\right)_{4} \cdot 2 \mathrm{H}{ }_{2} \mathrm{O} \rightarrow\left(\mathrm{NH}_{4}\right)_{2} \mathrm{UO}_{2}\left(\mathrm{NO}_{3}\right)_{4} \cdot \mathrm{H}_{2} \mathrm{O} \\
\rightarrow\left(\mathrm{NH}_{4}\right)_{2} \mathrm{UO}_{2}\left(\mathrm{NO}_{3}\right)_{4} \rightarrow \mathrm{NH}_{4} \mathrm{UO}_{2}\left(\mathrm{NO}_{3}\right)_{3} \rightarrow \mathrm{A}-\mathrm{UO}_{3} \\
\rightarrow \gamma-\mathrm{UO}_{3} \rightarrow \mathrm{U}_{3} \mathrm{O}_{8} \\
\mathrm{NH}_{4} \mathrm{UO}_{2}\left(\mathrm{NO}_{3}\right)_{3} \rightarrow \mathrm{A}-\mathrm{UO}_{3} \rightarrow \alpha-\mathrm{UO}_{3} \rightarrow \mathrm{U}_{3} \mathrm{O}_{8}\end{array}$ & Air \\
\hline & $\begin{array}{l}\left(\mathrm{NH}_{4}\right)_{2} \mathrm{UO}_{2}\left(\mathrm{NO}_{3}\right)_{4} \cdot 2 \mathrm{H}{ }_{2} \mathrm{O} \rightarrow\left(\mathrm{NH}_{4}\right)_{2} \mathrm{UO}_{2}\left(\mathrm{NO}_{3}\right)_{4} \cdot \mathrm{H}_{2} \mathrm{O} \\
\rightarrow\left(\mathrm{NH}_{4}\right)_{2} \mathrm{UO}_{2}\left(\mathrm{NO}_{3}\right)_{4} \rightarrow \mathrm{NH}_{4} \mathrm{UO}_{2}\left(\mathrm{NO}_{3}\right)_{3} \rightarrow \mathrm{A}-\mathrm{UO}_{3} \\
\rightarrow \gamma-\mathrm{UO}_{3} \rightarrow \alpha-\mathrm{U}_{3} \mathrm{O}_{8} \rightarrow \mathrm{UO}_{2} \\
\mathrm{NH}_{4} \mathrm{UO}_{2}\left(\mathrm{NO}_{3}\right)_{3} \rightarrow \mathrm{A}-\mathrm{UO}_{3} \rightarrow \beta-\mathrm{UO}_{3} \rightarrow \alpha-\mathrm{U}_{3} \mathrm{O}_{8} \rightarrow \mathrm{UO}_{2}\end{array}$ & $\mathrm{H}_{2}$ \\
\hline
\end{tabular}




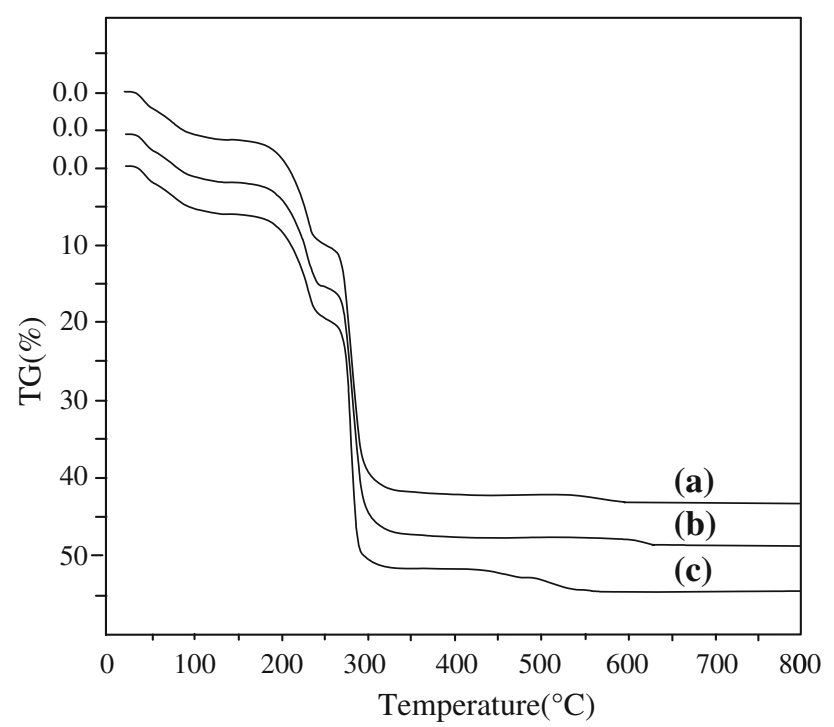

Fig. 9 TG curves of $\left(\mathrm{NH}_{4}\right)_{2} \mathrm{UO}_{2}\left(\mathrm{NO}_{3}\right)_{4} \cdot 2 \mathrm{H}_{2} \mathrm{O}$ in a $\mathrm{N}_{2}$, b air, and $\mathbf{c} \mathrm{H}_{2}$ atmosphere

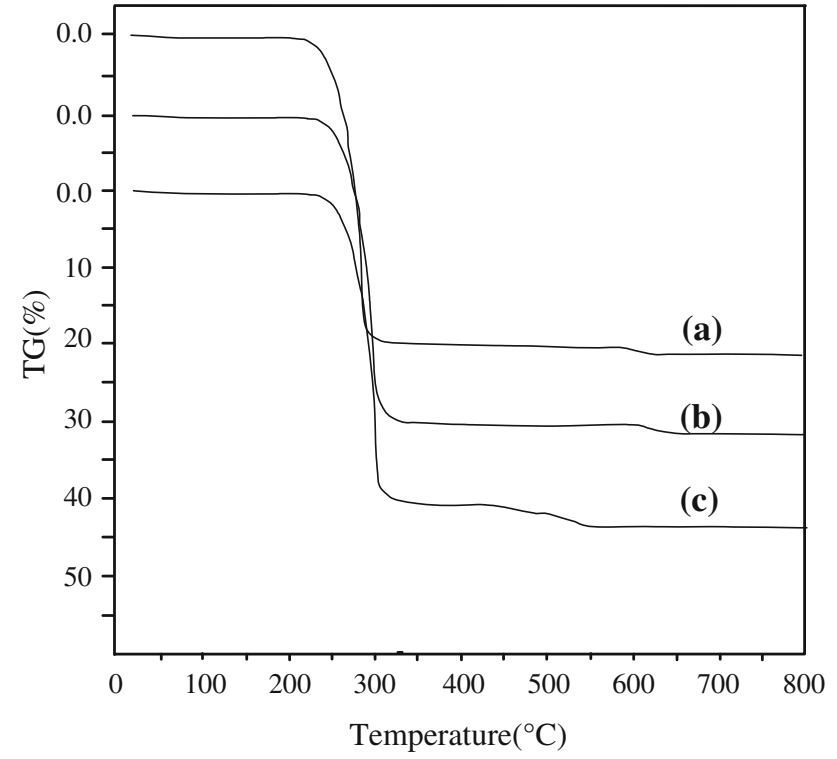

Fig. 10 TG curves of $\mathrm{NH}_{4} \mathrm{UO}_{2}\left(\mathrm{NO}_{3}\right)_{3}$ in a $\mathrm{N}_{2}$, b air, and c $\mathrm{H}_{2}$ atmosphere

hydrogen atmosphere up to $400{ }^{\circ} \mathrm{C}$, resulted in the production of $\mathrm{UO}_{3}\left(\mathrm{H}_{2} \mathrm{O}\right)_{0.15}$, which is amorphous hydrated urania. Govindan [16] reported that an amorphous $\mathrm{UO}_{3}\left(\mathrm{H}_{2} \mathrm{O}\right)_{x}$ was produced due to the loss of ammonia and thermal disassembly of carbonate oxy-anion during the thermal decomposition of AUC. It was found in this study, through an X-ray diffraction analysis, that the amorphous $\mathrm{UO}_{3}$ was crystallized into $\alpha-\mathrm{UO}_{3}$, $\beta$ - $\mathrm{UO}_{3}$ and $\gamma-\mathrm{UO}_{3}$ at $480{ }^{\circ} \mathrm{C}$ under the nitrogen and air atmospheres, and at $430{ }^{\circ} \mathrm{C}$ under a hydrogen atmosphere, respectively, yet no weight loss took place as shown by the TG curve. Therefore, it appears that the crystallizing stage took place simply due to a phase change.

\section{Conclusions}

An intermediate phase, amorphous $\mathrm{UO}_{3}$ was produced when $\left(\mathrm{NH}_{4}\right)_{2} \mathrm{UO}_{2}\left(\mathrm{NO}_{3}\right)_{4}$ and $\mathrm{NH}_{4} \mathrm{UO}_{2}\left(\mathrm{NO}_{3}\right)_{3}$ were thermally decomposed under air, nitrogen, and hydrogen atmosphere, regardless of the atmosphere used. $\gamma-\mathrm{UO}_{3}$ was produced as the intermediate product irrespective of the atmospheric gas used during the decomposition of $\left(\mathrm{NH}_{4}\right)_{2} \mathrm{UO}_{2}\left(\mathrm{NO}_{3}\right)_{4}$. $2 \mathrm{H}_{2} \mathrm{O}$. However, in the case of $\mathrm{NH}_{4} \mathrm{UO}_{2}\left(\mathrm{NO}_{3}\right)_{3}$, when decomposed under the nitrogen and air atmospheres, $\alpha-\mathrm{UO}_{3}$ was produced, whereas $\beta-\mathrm{UO}_{3}$ was produced under a hydrogen atmosphere.

The reaction paths of $\left(\mathrm{NH}_{4}\right)_{2} \mathrm{UO}_{2}\left(\mathrm{NO}_{3}\right)_{4} \cdot 2 \mathrm{H}_{2} \mathrm{O}$ and $\mathrm{NH}_{4} \mathrm{UO}_{2}\left(\mathrm{NO}_{3}\right)_{3}$ under each atmosphere were as follows:

- Under the nitrogen atmosphere

- $\left(\mathrm{NH}_{4}\right)_{2} \mathrm{UO}_{2}\left(\mathrm{NO}_{3}\right)_{4} \cdot 2 \mathrm{H}_{2} \mathrm{O} \rightarrow\left(\mathrm{NH}_{4}\right)_{2} \mathrm{UO}_{2}\left(\mathrm{NO}_{3}\right)_{4}$. $\mathrm{H}_{2} \mathrm{O} \rightarrow\left(\mathrm{NH}_{4}\right)_{2} \mathrm{UO}_{2}\left(\mathrm{NO}_{3}\right)_{4} \rightarrow \mathrm{NH}_{4} \mathrm{UO}_{2}\left(\mathrm{NO}_{3}\right)_{3} \rightarrow$ $\mathrm{A}-\mathrm{UO}_{3} \rightarrow \gamma-\mathrm{UO}_{3} \rightarrow \mathrm{U}_{3} \mathrm{O}_{8}$

- $\mathrm{NH}_{4} \mathrm{UO}_{2}\left(\mathrm{NO}_{3}\right)_{3} \rightarrow \mathrm{A}-\mathrm{UO}_{3} \rightarrow \alpha-\mathrm{UO}_{3} \rightarrow \mathrm{U}_{3} \mathrm{O}_{8}$

- Under the air atmosphere

- $\left(\mathrm{NH}_{4}\right)_{2} \mathrm{UO}_{2}\left(\mathrm{NO}_{3}\right)_{4} \cdot 2 \mathrm{H}_{2} \mathrm{O} \rightarrow\left(\mathrm{NH}_{4}\right)_{2} \mathrm{UO}_{2}\left(\mathrm{NO}_{3}\right)_{4}$. $\mathrm{H}_{2} \mathrm{O} \rightarrow\left(\mathrm{NH}_{4}\right)_{2} \mathrm{UO}_{2}\left(\mathrm{NO}_{3}\right)_{4} \rightarrow \mathrm{NH}_{4} \mathrm{UO}_{2}\left(\mathrm{NO}_{3}\right)_{3} \rightarrow$ $\mathrm{A}-\mathrm{UO}_{3} \rightarrow \gamma-\mathrm{UO}_{3} \rightarrow \mathrm{U}_{3} \mathrm{O}_{8}$

- $\mathrm{NH}_{4} \mathrm{UO}_{2}\left(\mathrm{NO}_{3}\right)_{3} \rightarrow \mathrm{A}-\mathrm{UO}_{3} \rightarrow \alpha-\mathrm{UO}_{3} \rightarrow \mathrm{U}_{3} \mathrm{O}_{8}$

- Under the hydrogen atmosphere

- $\left(\mathrm{NH}_{4}\right)_{2} \mathrm{UO}_{2}\left(\mathrm{NO}_{3}\right)_{4} \cdot 2 \mathrm{H}_{2} \mathrm{O} \rightarrow\left(\mathrm{NH}_{4}\right)_{2} \mathrm{UO}_{2}\left(\mathrm{NO}_{3}\right)_{4}$. $\mathrm{H}_{2} \mathrm{O} \rightarrow\left(\mathrm{NH}_{4}\right)_{2} \mathrm{UO}_{2}\left(\mathrm{NO}_{3}\right)_{4} \rightarrow \mathrm{NH}_{4} \mathrm{UO}_{2}$ $\left(\mathrm{NO}_{3}\right)_{3} \rightarrow \mathrm{A}-\mathrm{UO}_{3} \rightarrow \gamma-\mathrm{UO}_{3} \rightarrow \alpha-\mathrm{U}_{3} \mathrm{O}_{8} \rightarrow \mathrm{UO}_{2}$

- $\mathrm{NH}_{4} \mathrm{UO}_{2}\left(\mathrm{NO}_{3}\right)_{3} \rightarrow \mathrm{A}-\mathrm{UO}_{3} \rightarrow \beta-\mathrm{UO}_{3} \rightarrow \alpha-\mathrm{U}_{3}$ $\mathrm{O}_{8} \rightarrow \mathrm{UO}_{2}$

Open Access This article is distributed under the terms of the Creative Commons Attribution Noncommercial License which permits any noncommercial use, distribution, and reproduction in any medium, provided the original author(s) and source are credited.

\section{References}

1. Davis NC, Griffiin CW (1982) PNL-4305 Pacific Northwest Laboratory

2. Notz KJ, Haas PA (1989) Conf-891206-1

3. El-Mamoon Yahia M, El-Fekey SA (1996) Radiochim Acta 72:205

4. Halldahl L, Nygren M (1986) J Nucl Mat 138:99

5. Kim BH, Hwang ST, Lee KY (2001) J Korean Ind Eng Chem $12: 300$

6. Ippolitova EA, Pechurova NI, Gribennik EN (1961) ANL Trans 33:114. Argone National Laboratory

7. Ainscough B, Oldfield BW (1962) J Appl Chem 12

8. Woolfrey JL (1974) AAEC/E-329. Australian Atomic Energy Commission 
9. Cordfunke EH (1962) J Inorg Nucl Chem 24:303

10. Landspersky $H$ (1963) International symposium on new nuclear fuel materials, vol 1. Prague, p 79

11. Rodriguez SA, Hernandez RR, Ma Garcia CR (1995) Vib Spectrose 9:215

12. Kim EH (1995) Ph.D thesis, Seogang University, Seoul, Korea
13. Sato T, Osawa F, Shiota S (1985) Thermochim Acta 37:313

14. Halldahl L, Sorensen T (1979) Thermochim Acta 29:253

15. Price GH (1973) AAEC/E276. Australian Atomic Energy Commission

16. Govindan P (2002) J Radioanal Nucl Chem 254:65 